\section{Nitrous oxide potentiates vecuronium neuromuscular blockade in humans}

This study was designed to measure the potency of vecuronium with and without nitrous oxide. Anaesthesia was induced with thiopentone and fentanyl in 56 adult patients. The subjects were randomly assigned to receive nitrous oxide, $70 \%$, or intermittent boluses of thiopentone and fentanyl for maintenance of anaesthesia. Train-of-four stimulation was applied to the ulnar nerve every $20 \mathrm{sec}$, and the force of contraction of the adductor pollicis muscle was measured. Vecuronium, 20, 30 or 40 $\mu \mathrm{g} \cdot \mathrm{kg}^{-1}$ was given by random allocation five minutes after induction of anaesthesia. Maximum depression of the first response $\left(T_{1}\right)$ in the train-of-four was measured, and doseresponse curves were constructed. In the absence of nitrous oxide, the $E D_{50}$ and $E D_{95}$ were mean \pm standard error of the mean $(S E M), 29.2 \pm 1.8$ and $59.3 \pm 3.6 \mu \mathrm{g} \cdot \mathrm{kg}^{-1}$, respectively. In the group receiving nitrous oxide, these values were 25.3 \pm 1.2 and $42.3 \pm 2.0 \mu \mathrm{g} \cdot \mathrm{kg}^{-1}$ respectively. By analysis of covariance, the dose-response curves were shown to be shifted with respect to one another $(P<0.05)$. Administration of nitrous oxide was associated with a $19.5 \%$ increase in potency (95\% confidence limits: 1.7 to $40.4 \%$ ). It is concluded that nitrous oxide has a slight potentiating effect on neuromuscular blockade, and that this effect occurs within five to ten minutes after the beginning of its administration.

Le but de l'étude était de mesurer la puissance du vécuronium avec ou sans protoxyde d'azote. On a induit l'anesthésie avec du thiopental et du fentanyl chez 56 adultes. Pour l'entretien de l'anesthésie, les sujets ont reçu, au hasard, soit du protoxyde

\section{Key Words}

ANAESTHETICS, GASES: nitrous oxide;

DRUG INTERACTIONS: nitrous oxide, vecuronium; MONITORING: neuromuscular function, train-of-four; NEUROMUSCULAR RELAXANTS: vecuronium.

From the Departments of Anaesthesia, Royal Victoria Hospital, and McGill University, Montreal (Quebec) Canada.

Address correspondence to: Dr. François Donati, Department of Anaesthesia, Royal Victoria Hospital, 687 Pine Avenue West, Montreal (Quebec) Canada H3A 1 A1. Accepted for publication 24th April, 1991. d'azote, 70\%, soit des injections répétées de thiopental et de fentanyl. On a appliqué une stimulation en mode train-de-quatre près du nerf cubital toutes les $20 \mathrm{sec}$, et on a mesuré la force de contraction de l'adducteur du pouce. Après l'induction de l'anesthésie, on a injecté du vécuronium, 20, 30 ou 40 $\mu \mathrm{g} \cdot \mathrm{kg}^{-1}$, choisi au hasard. Le bloc maximum du premier élément du train-de-quatre $\left(T_{1}\right)$ a été mesuré pour calculer les courbes de dose-action. Sans protoxyde d'azote, on a trouvé une $D A_{50}$ (moyenne \pm écart type de la moyenne) de 29,2 $\pm 1,8$ $\mu \mathrm{g} \cdot \mathrm{kg}^{-1}$ et une $\mathrm{DA}_{95}$ de $59,3 \pm 3,6 \mu \mathrm{g} \cdot \mathrm{kg}^{-1}$. Avec le protoxyde d'azote, ces valeurs s'établissaient à $25,3 \pm 1,2$ et $42,3 \pm 2,0 \mu \mathrm{g} \cdot \mathrm{kg}^{-1}$, respectivement. On a montré par analyse de covariance que les courbes de dose-action étaient décalées l'une par rapport à l'autre $(P<0,05)$. L'administration de protoxyde d'azote a entraîné une augmentation de puissance de $19,5 \%$ (limites de confiance à $95 \%: 1,7-40,4 \%$ ). On en conclut que le protoxyde d'azote potentialise un peu le bloc neuromusculaire, et que cet effet survient dans les cinq à dix premières minutes d'administration du gaz.

Dosage recommendations for neuromuscular blocking agents are based on dose-response studies. Several factors are known to influence dose-response relationships, such as the presence of volatile anaesthetic agents. ${ }^{1-4}$ For this reason, potency estimates obtained during a thiopentonenarcotic-nitrous oxide anaesthetic are considered more reliable. It is assumed that nitrous oxide is free of any potentiating effect on the neuromuscular junction.

However, the effect of nitrous oxide on nondepolarizing neuromuscular blocking drugs has not been evaluated in humans. In rats, introduction of nitrous oxide was found to reduce twitch height, ${ }^{5}$ but this effect was not seen in cats. ${ }^{6}$ In humans, the depolarizing agent succinylcholine was found to produce a greater degree of blockade if nitrous oxide was added to the induction agent. ${ }^{7}$ Such a study has not been performed for nondepolarizing muscle relaxants.

Dose-response data are useful to determine "intubating" doses of nondepolarizing agents. However, the neuromuscular blocking drug is normally given immediately after induction of anaesthesia, before the patient has 
received any nitrous oxide. Therefore, it is important to determine the extent to which nitrous oxide could modify the response to these drugs. This study was designed to compare the potency of vecuronium, an agent commonly used to facilitate tracheal intubation, in the presence and absence of nitrous oxide.

\section{Methods}

The protocol was approved by the Hospital Ethics Committee. After verbal informed consent was obtained, 56 ASA physical status I or II adults, between the ages of 18 and $75 \mathrm{yr}$, were included in the study. The patients were scheduled for various orthopaedic, abdominal or gynaecological elective procedures. Patients with hepatic, renal or neuromuscular diseases were excluded, as were those with malnutrition, electrolyte abnormalities, and those taking any medication known to or suspected of interfering with neuromuscular function. Also excluded were patients who deviated from their ideal body weight by more than $20 \%$.

The patients received premedication with diazepam, 5-10 mg po, $60 \mathrm{~min}$ before the expected start of the surgical procedure. On arrival in the operating room, an intravenous catheter was placed in the forearm. Arterial blood pressure, ECG, and oxygen saturation were monitored. Anaesthesia was induced with thiopentone, 5-7 $\mathrm{mg} \cdot \mathrm{kg}^{-1}$, and fentanyl, $1-3 \mu \mathrm{g} \cdot \mathrm{kg}^{-1}$. The patients were randomly assigned to have their lungs ventilated manually, with either oxygen, $100 \%$, or a mixture of nitrous oxide, $70 \%$, and oxygen, $30 \%$. Additional boluses of thiopentone and/or fentanyl were given, if necessary, to maintain anaesthesia. End-tidal $\mathrm{CO}_{2}$ was kept in the range $30-40 \mathrm{mmHg}$. The level of anaesthesia was judged adequate if spontaneous movements were absent and if arterial blood pressure remained below the pre-anaesthetic value. End-tidal values for the concentration of $\mathrm{CO}_{2}$, oxygen and nitrous oxide were measured with a mass spectrometer (SARA). After maximum blockade was reached, the study was terminated and the remainder of the anaesthetic was left at the anaesthetist's discretion.

Supramaximal train-of-four stimulation ( $2 \mathrm{~Hz}$ for $2 \mathrm{sec}$ ) was applied every $20 \mathrm{sec}$, via surface electrodes at the wrist. These pulses, $0.1 \mathrm{~ms}$ in duration, were supplied by a Datex NMT221 monitor. The hand and forearm were immobilized in a splint, and the force of contraction of the adductor pollicis muscle was measured with a GRASS FT10 transducer. Stimulation commenced four minutes after induction of anaesthesia, and a baseline recording was established. One minute later, vecuronium was injected. The patients were randomized to receive a dose of 20,30 , or $40 \mu \mathrm{g} \cdot \mathrm{kg}^{-1}$. The recording was continued until the response to the first stimulus in the train $\left(\mathrm{T}_{1}\right)$ was
TABLE I Demographic data (mean \pm SEM where applicable)

\begin{tabular}{lcc}
\hline & \multicolumn{2}{c}{ Nitrous oxide } \\
\cline { 2 - 3 } & Absent & Present \\
\hline Number & 28 & 28 \\
Sex $(\mathrm{M} / \mathrm{F})$ & $11 / 17$ & $11 / 17$ \\
Age $(\mathrm{yr})$ & $43.4 \pm 2.5$ & $41.6 \pm 2.6$ \\
Weight $(\mathrm{kg})$ & $63.4 \pm 2.2$ & $63.1 \pm 2.2$ \\
Height $(\mathrm{cm})$ & $166.8 \pm 1.4$ & $166.0 \pm 1.8$ \\
Dose of thiopentone $\left(\mathrm{mg} \cdot \mathrm{kg}^{-1}\right)$ & $7.67 \pm 0.31$ & $7.23 \pm 0.27$ \\
\hline
\end{tabular}

stable for at least three consecutive trains. At the end of the recording, additional vecuronium was administered to facilitate tracheal intubation, mechanical ventilation was instituted, and the surgical procedure was allowed to start.

Dose-response curves were constructed from the logit transformation of $T_{1}$ depression versus the logarithm of the vecuronium dose for each anaesthetic technique. The slopes of the curves were compared for parallelism using unpaired Student's test. If the slopes were not statistically different, analysis of covariance was used to compare the regression lines. The results are expressed as means $\pm \mathrm{SEM}$, except $\mathrm{ED}_{50}$ and $\mathrm{ED}_{90}$ values, which are presented as mean \pm standard error of estimate for the mean. A $P$ value of $<0.05$ was considered to indicate statistically significant differences.

\section{Results}

Both groups were comparable with respect to sex, age, weight and height and the dose of thiopentone was similar in both groups (Table I).

The dose-response curves are shown in the Figure. The slopes of the regression lines did not differ significantly for parallelism. The dose-response relationship of the patients who did not receive nitrous oxide was shifted to the right by $19.5 \%$ (95\% confidence limits: $1.5-40.4 \% ; P$ $<0.05$ ). The estimates of $\mathrm{ED}_{50}$ and $\mathrm{ED}_{95}$ are presented in Table II. The time to maximum blockade was independent of dose, and was comparable in both groups (Table III).

\section{Discussion}

The results of the study demonstrate that nitrous oxide, $70 \%$, administered for five to ten minutes, is associated with an increase in potency of vecuronium of approximately $20 \%$. This difference was found in patients who received vecuronium at a fixed time after induction of anaesthesia. Thus, the phenomenon cannot be attributed to a different duration of anaesthesia in both groups.

The five-minute interval between induction of anaesthesia and administration of vecuronium was chosen to allow end-tidal concentrations of nitrous oxide to reach a 


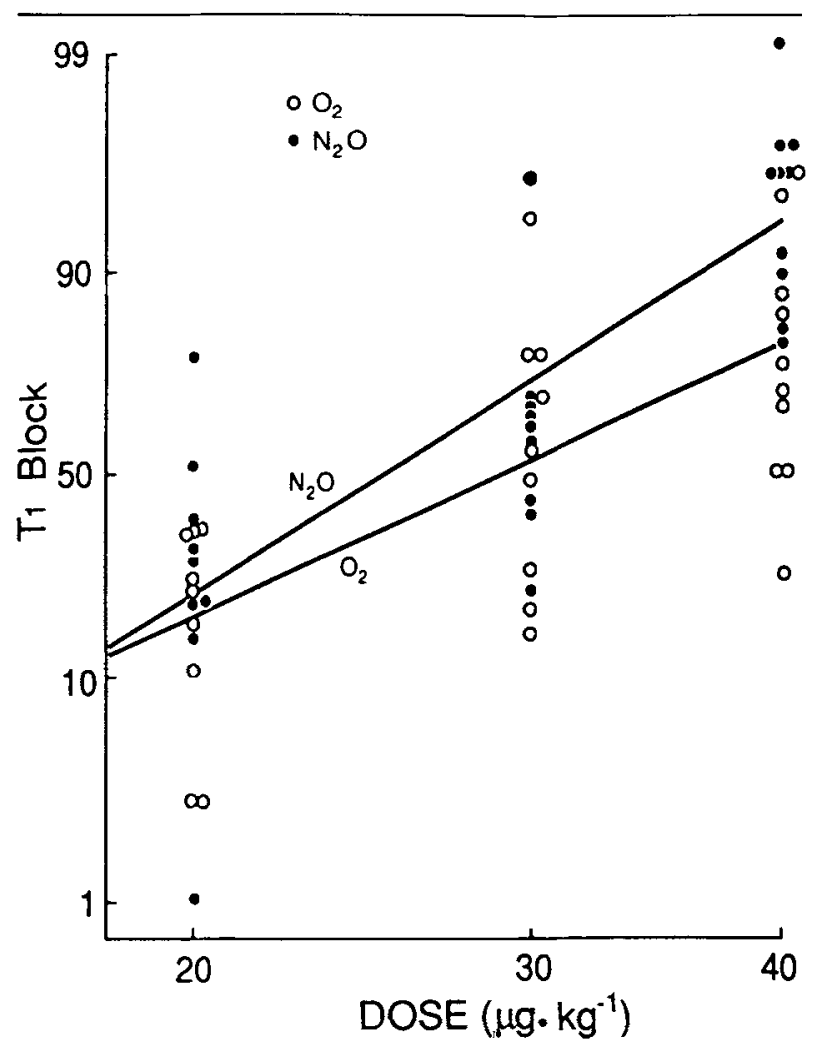

FIGURE First twitch blockade (logit scale) versus dose (log scale) with and without nitrous oxide.

TABLE II Estimate of $\mathrm{ED}_{50}$ and $\mathrm{ED}_{95}\left(\mu \mathrm{g} \cdot \mathrm{gg}^{-1} ;\right.$ mean $\left.\pm \mathrm{SEM}\right)$

\begin{tabular}{lll}
\hline \multicolumn{3}{c}{ Nitrous oxide } \\
\cline { 2 - 3 } & Absent & Present \\
\hline ED $_{50}$ & $29.2 \pm 1.8$ & $25.3 \pm 1.2$ \\
ED $_{95}$ & $59.3 \pm 3.6$ & $42.3 \pm 2.0$ \\
\hline
\end{tabular}

TABLE III Time to maximum blockade (min; mean \pm SEM)

\begin{tabular}{lll}
\hline & \multicolumn{2}{l}{ Nitrous oxide } \\
\cline { 2 - 3 } Dose $\left(\mu \mathrm{g} \cdot \mathrm{kg}^{-1}\right)$ & Absent & Present \\
\hline 20 & $6.2 \pm 0.5$ & $6.6 \pm 0.4$ \\
30 & $7.2 \pm 0.5$ & $6.8 \pm 0.3$ \\
40 & $6.5 \pm 0.4$ & $5.7 \pm 0.4$ \\
\hline
\end{tabular}

plateau. Measurement of these concentrations with a mass spectrometer confirmed that this was the case. The pattern of stimulation was the same in all groups, and train-offour stimulation was commenced at a fixed time before the injection of vecuronium, because the duration of stimulation can affect the onset of neuromuscular blockade. ${ }^{8}$
A similar methodology was adoped in a previous study, which involved succinylcholine. The twitch depression produced by succinylcholine, $0.3 \mathrm{mg} \cdot \mathrm{kg}^{-1}$, was found to be greater in the presence of nitrous oxide. ${ }^{7}$ Doseresponse data were not obtained in the study involving succinylcholine, but the results appear quantitatively similar to those obtained in the present study with vecuronium.

In the present study, maximum vecuronium blockade occurred approximately 10-12 min after induction of anaesthesia and first introduction of nitrous oxide. This time interval is considerably shorter than the $30 \mathrm{~min}$ quoted as the time constant for saturation in muscle tissue. ${ }^{9}$ If the site of interaction of nitrous oxide with vecuronium were at the neuromuscular junction, it is expected that prolonging the exposure to nitrous oxide (beyond 10-12 $\mathrm{min}$ ) would increase the degree of potentiation of vecuronium neuromuscular blockade. However, in most studies on the potency of vecuronium, administration periods for nitrous oxide have been longer than in the present study, and the reported $\mathrm{ED}_{50} \mathrm{~s}(20-28$ $\left.\mu \mathrm{g} \cdot \mathrm{kg}^{-1}\right)^{10-14}$ were similar to the figures reported in the present study $\left(25 \mu \mathrm{g} \cdot \mathrm{kg}^{-1}\right)$. This suggests that the interaction between nitrous oxide and vecuronium takes place within a short period of time and might occur at a site other than the neuromuscular junction. An alternative explanation for the phenomenon would be that the blood flow to the neuromuscular junction is greater than the blood flow to muscle as a whole, thus shortening the time course of action of nitrous oxide. ${ }^{15}$

A potentiating effect of nitrous oxide on neuromuscular blockade has been reported in rats anaesthetized with pentobarbitone and urethane. ${ }^{5}$ Introduction of nitrous oxide depressed twitch height in the presence of a muscle relaxant. However, this finding was not reported in similar experiments performed in cats anaesthetized with chloralose and pentobarbitone. ${ }^{6}$ In humans, Miller reported that, in patients anaesthetized with halothane and given a constant infusion of d-tubocurarine, the introduction of nitrous oxide did not alter twitch height. ${ }^{16}$ These apparently contradictory findings could perhaps be explained by the fact that different depths of anaesthesia were achieved in these experiments, and that the effect of nondepolarizing muscle relaxants could be critically dependent on the depth of anaesthesia over a certain range. The potency of d-tubocurarine was increased considerably ten minutes after induction of anaesthesia with thiopentone, nitrous oxide and halothane, compared with the awake state, ${ }^{15}$ suggesting that anaesthesia, per se, alters the response to neuromuscular blockers. In the present study, it is possible that the thiopentone-fentanyl anaesthetic was lighter than the thiopentone-fentanylnitrous oxide anaesthetic, and this may account for the 
shift in the dose-response curve. However, if a deeper level of anaesthesia had been reached, as presumably occurred in Miller's report, ${ }^{16}$ nitrous oxide would have been ineffective in potentiating neuromuscular blockade.

Irrespective of the mechanism involved, the results of the study explain, in part, why doses exceeding the previously quoted $\mathrm{ED}_{95}$ values for vecuronium are required if this drug is given to facilitate tracheal intubation. Dose-response data are normally obtained with narcoticnitrous oxide anaesthesia, and doses required to achieve 95\% blockade are slightly higher after injection of an induction agent and a narcotic drug. Other factors also play a role, such as the wide interindividual variation in response, ${ }^{17}$ the relative resistance of respiratory ${ }^{18}$ and laryngeal muscles, ${ }^{19}$ and the tendency of clinicians to attempt intubation before maximal blockade has been reached. Nevertheless, the presence of nitrous oxide might be considered as an unnecessary source of variability, and dosage requirements for tracheal intubation should be based on data obtained without nitrous oxide.

\section{References}

1 Miller RD, Way WL, Dolan WM, Stevens WC, Eger $E I$. The dependence of pancuronium- and d-tubocurarineinduced neuromuscular blockades on alveolar concentrations of halothane and forane. Anesthesiology 1971; 37: 573-81.

2 Fogdall RP, Miller RD. Neuromuscular effects of enflurane, alone and combined with d-tubocurarine, pancuronium, and succinylcholine, in man. Anesthesiology 1975; 42: 173-8.

3 Rupp SM, Miller RD, Gencarelli PJ. Vecuronium-induced neuromuscular blockade during enflurane, isoflurane, and halothane anesthesia in humans. Anesthesiology 1984; 60: $102-5$.

4 Rupp SM, McChristian JW, Miller RD. Neuromuscular effects of atracurium during halothane-nitrous oxide and enflurane-nitrous oxide anesthesia in humans. Anesthesiology 1985; 63: 16-9.

5 McIndewar IC, Marshall RJ. Interactions between the neuromuscular blocking drug ORG NC45 and some anaesthetic, analgesic and antimicrobial agents. $\mathrm{Br} \mathrm{J}$ Anaesth 1981; 53: 785-92.

6 Kinjo M, Nagashima H, Duncalf D, Goldiner PL, Foldes $F F$. Nitrous oxide increases the neuromuscular blocking effect of nondepolarizing muscle relaxants (Abstract). Anesthesiology 1987; 67: A372.

7 Szalados JE, Donati F, Bevan DR. Nitrous oxide potentiates succinylcholine blockade in humans. Anesth Analg 1991; 72: 18-21.

8 Curran $M J$, Donati $F$, Bevan $D R$. Onset and recovery of atracurium and suxamethonium-induced neuromuscular blockade with simultaneous train-of-four and single twitch stimulation. Br J Anaesth 1987; 59: 989-94.

9 Eger EI II. Anesthetic uptake and action. Baltimore: Williams and Wilburys 1974; 88.

$10 \emptyset$ rding H, Skovgaard LT, Engbaek J, Viby-Mogensen J. Dose-response curves for vecuronium during halothane and neurolept anaesthesia: single bolus versus cumulative method. Acta Anaesthesiol Scand 1985; 29: 121-4.

$11 O^{\prime}$ Hara DA, Fragen RJ, Shanks CA. The effects of age on the dose-response curves for vecuronium in adults. Anesthesiology 1985; 63: 542-4.

12 Ornstein E, Matteo RS, Schwartz AE, Silverberg PA, Young WL, Diaz J. The effect of phenytoin on the magnitude and duration of neuromuscular block following atracurium or vecuronium. Anesthesiology 1987; 67: 191-6.

13 Smith $C E$, Donati $F$, Bevan DR. Cumulative doseresponse with infusion: a technique to determine neuromuscular blocking potency of atracurium and vecuronium. Clin Pharmacol Ther 1988; 44: 56-64.

14 Gibson FM, Mirakhur RK, Clarke RSJ, Lavery GG. Comparison of cumulative single bolus dose techniques for determining the potency of vecuronium. $\mathrm{Br} \mathbf{J}$ Anaesth 1985; 57: 1060-2.

15 Miller RD, Crique M, Eger EI. Duration of halothane anesthesia and neuromuscular blockade with d-tubocurarine. Anesthesiology 1976; 44: 206-10.

16 Miller RD. Neuromuscular effect of nitrous oxide. In: Edmond I Eger II (Ed.). Nitrous Oxide/ $\mathrm{N}_{2} \mathrm{O}$. New York: Elsevier. 1985; 177-84.

17 Katz RL. Neuromuscular effects of d-tubocurarine, edrophonium and neostigmine in man. Anesthesiology 1967; 28: 327-36.

18 Laycock JRD, Donati F, Smith CE, Bevan DR. Potency of atracurium and vecuronium at the diaphragm and the adductor pollicis muscle. Br J Anaesth 1988; 61: 286-91.

19 Donati F, Meistelman C, Plaud B. Vecuronium neuromuscular blockade at the adductor muscles of the larynx and adductor pollicis. Anesthesiology 1991; 74: 833-7. 